\title{
Commentary: Police and Suicide Prevention
}

\author{
Leo Sher ${ }^{1,2 *}$ \\ 'James J. Peters Veterans' Administration Medical Center, Bronx, NY, USA, ${ }^{2}$ Icahn School of Medicine at Mount Sinai, \\ New York, NY, USA
}

Keywords: police, suicide, drugs, antisocial behavior

\section{A commentary on}

Police and Suicide Prevention

by Marzano L, Smith M, Long M, Kisby C, Hawton K. Crisis (2016). doi: 10.1027/0227-5910/a000381

I read with interest an important article, "Police and suicide prevention" that was recently published in Crisis (1). The authors developed and evaluated training in suicide awareness and prevention for frontline police officers. Areas covered in the training module included the role of police officers in suicide prevention, the main characteristics of individuals who engage in suicidal and self-harm acts, how to approach and question individuals suspected to be at risk of suicide, how to ascertain the level of risk of individuals suspected to be suicidal or expressing suicidal ideation, how to refer individuals at risk of suicide to the services most appropriate for their specific needs and level of risk, and other

Edited by: Frederick Robert Carrick, University of Cambridge, USA

Reviewed by:

Marlene Belew Huff,

University of Kentucky, USA Jean-Philippe Raynaud,

$\mathrm{CHU}$ de Toulouse, France

Ahmed Eid Elaghoury,

Ministry of Health, Egypt Aron Tendler,

Brainsway, USA

*Correspondence:

Leo Sher

drleosher@gmail.com

Specialty section: This article was submitted to Child Health and Human Development, a section of the journal

Frontiers in Public Health

Received: 20 April 2016 Accepted: 26 May 2016

Published: 08 June 2016

Citation:

Sher L (2016) Commentary: Police and Suicide Prevention.

Front. Public Health 4:119. doi: 10.3389/fpubh.2016.00119 issues. All officers who participated in the training program were asked to complete a questionnaire before, immediately after, and 6 months after undertaking training, to measure changes in knowledge, confidence, and attitudes, regarding suicide prevention. The authors concluded that training in suicide prevention appears to have been well received and to have had a beneficial impact on officers' attitudes, confidence, and knowledge. The results of this study show that police may play a role in suicide prevention. The authors also astutely noted that providing training with regard to suicidality may help the officers themselves in terms of increasing awareness and recognition of mental health issues that might affect them personally, their colleagues, or their family members. This is important because substantial job-related stressors and exposures lead to increased risk for psychiatric issues, including suicidal behavior among police officers (2-4). It should be noted that studies related to crisis intervention and suicide prevention training for police officers have been conducted in several countries (5-12).

Police may play a role in suicide prevention not only because police officers may prevent suicides when they interact with suicidal individuals. Police may contribute to suicide prevention indirectly.

The use of illicit drugs is associated with suicide (13). For example, a number of cross-sectional or retrospective studies have found an association between cannabis use and suicidal ideation, suicide attempts, or completed suicide (14-20). In one of these studies, a research group in Brisbane, Australia examined same sex twin pairs discordant for cannabis dependence to determine relationships between cannabis use and major depressive disorder, suicidal behavior, and suicidal ideations (14). Cannabis-dependent individuals had odds of suicide attempt or ideation that was 2.5-2.9 times higher than their non-cannabis-dependent twin. In another example, a research report suggests that heroin users are 14 times more likely than peers to die from suicide (21). Deaths among heroin users attributed to suicide range from 3 to 35\% (21). A study in Rome, Italy has reported excess suicide mortality of 6.3 times among heroin users to that expected among matched peers (22). Police and other law enforcement agencies in many countries work hard to fight drug crimes. For example, in the U.S., there is a drug arrest every 19 seconds (23). When police fight drug trafficking and distribution, they decrease the availability of drugs, which may reduce suicides. 
Antisocial behavior is also associated with suicide (24-28). For example, it has been reported that "Studies have revealed antisocial personality disorder or criminal behavior to be a predictor of subsequent suicide attempts" (28). Police Community Outreach Programs and other similar projects may reduce antisocial behavior, especially among young people (21-32). Consequently, this may reduce suicides. In summary,

\section{REFERENCES}

1. Marzano L, Smith M, Long M, Kisby C, Hawton K. Police and suicide prevention. Crisis (2016). doi:10.1027/0227-5910/a000381

2. Stanley IH, Hom MA, Joiner TE. A systematic review of suicidal thoughts and behaviors among police officers, firefighters, EMTs, and paramedics. Clin Psychol Rev (2016) 44:25-44. doi:10.1016/j.cpr.2015.12.002

3. Stuart H. Suicidality among police. Curr Opin Psychiatry (2008) 21(5):505-9. doi:10.1097/YCO.0b013e328305e4c1

4. Violanti JM, Mnatsakanova A, Burchfiel CM, Hartley TA, Andrew ME. Police suicide in small departments: a comparative analysis. Int J Emerg Ment Health (2012) 14(3):157-62.

5. Helfgott JB, Hickman MJ, Labossiere AP. A descriptive evaluation of the Seattle Police Department's crisis response team officer/mental health professional partnership pilot program. Int J Law Psychiatry (2016) 44:109-22. doi:10.1016/j.ijlp.2015.08.038

6. Compton MT, Broussard B, Reed TA, Crisafio A, Watson AC. Surveys of police chiefs and sheriffs and of police officers about CIT programs. Psychiatr Serv (2015) 66(7):760-3. doi:10.1176/appi.ps.201300451

7. Skeem J, Bibeau L. How does violence potential relate to crisis intervention team responses to emergencies? Psychiatr Serv (2008) 59(2):201-4. doi:10.1176/appi.ps.59.2.201

8. Ritter C, Teller JL, Marcussen K, Munetz MR, Teasdale B. Crisis intervention team officer dispatch, assessment, and disposition: interactions with individuals with severe mental illness. Int J Law Psychiatry (2011) 34(1):30-8. doi:10.1016/j.ijlp.2010.11.005

9. Vermette HS, Pinals DA, Appelbaum PS. Mental health training for law enforcement professionals. J Am Acad Psychiatry Law (2005) 33(1):42-6.

10. Kirst M, Francombe Pridham K, Narrandes R, Matheson F, Young L, Niedra $\mathrm{K}$, et al. Examining implementation of mobile, police-mental health crisis intervention teams in a large urban center. J Ment Health (2015) 24(6):369-74. doi:10.3109/09638237.2015.1036970

11. Lukaschek K, Baumert J, Ladwig KH. Behaviour patterns preceding a railway suicide: explorative study of German Federal Police officers' experiences. BMC Public Health (2011) 11:620. doi:10.1186/1471-2458-11-620

12. Kohrt BA, Blasingame E, Compton MT, Dakana SF, Dossen B, Lang F, et al. Adapting the crisis intervention team (CIT) model of police-mental health collaboration in a low-income, post-conflict country: curriculum development in Liberia, West Africa. Am J Public Health (2015) 105(3):e73-80. doi:10.2105/AJPH.2014.302394

13. Bohn M, Sher L. Suicide and substance abuse. 3rd ed. In: Kranzler HR, Korsmeyer P, editors. Encyclopedia of Drugs, Alcohol \& Addictive Behavior. Greenwich, CT: Macmillan Publishing Co. (2008). p. 70-5.

14. Lynskey MT, Glowinski AL, Todorov AA, Bucholz KK, Madden PA, Nelson EC, et al. Major depressive disorder, suicidal ideation, and suicide attempt in twins discordant for cannabis dependence and early-onset cannabis use. Arch Gen Psychiatry (2004) 61:1026-32. doi:10.1001/archpsyc.61. 10.1026

15. Serafini G, Pompili M, Innamorati M, Rihmer Z, Sher L, Girardi P. Can cannabis increase the suicide risk in psychosis? A critical review. Curr Pharm Des (2012) 18(32):5165-87. doi:10.2174/138161212802884663

16. Beautrais AL, JoycePR,Mulder RT.Cannabisabuseandserioussuicideattempts. Addiction (1999) 94:1155-64. doi:10.1046/j.1360-0443.1999.94811555.x

17. Chabrol H, Chauchard E, Girabet J. Cannabis use and suicidal behaviours in high-school students. Addict Behav (2008) 33:152-5. doi:10.1016/j. addbeh.2007.04.029 good police work may decrease suicide rates, directly and indirectly.

\section{AUTHOR CONTRIBUTIONS}

The author confirms being the sole contributor of this work and approved it for publication.

18. Huas C, Hassler C, Choquet M. Has occasional cannabis use among adolescents also to be considered as a risk marker? Eur J Public Health (2008) 18:626-9. doi:10.1093/eurpub/ckn065

19. Kung H, Pearson JL, Liu X. Risk for male and female suicide decedents ages 15-64 in the United States. Results from the 1993 National Mortality Followback Survey. Soc Psychiatry Psychiatr Epidemiol (2003) 38:419-26. doi:10.1007/s00127-003-0656-x

20. Arendt M, Munk-Jørgensen P, Sher L, Jensen SO. Mortality following treatment for cannabis use disorders: predictors and causes. J Subst Abuse Treat (2013) 44(4):400-6. doi:10.1016/j.jsat.2012.09.007

21. Darke S, Ross J. Suicide among heroin users: rates, risk factors and methods. Addiction (2002) 97(11):1383-94. doi:10.1046/j.1360-0443.2002.00214.x

22. Perucci CA, Davoli M, Rapiti E, Abeni DD, Forastieri F. Mortality of intravenous drug users in Rome: a cohort study. Am J Public Health (1991) 81:1307-10. doi:10.2105/AJPH.81.10.1307

23. U.S. Department of Justice, Federal Bureau of Investigation. Crime in the United States, 2009. (2010). Table 29. Available from: http://www2.fbi.gov/ ucr/cius2009/arrests/index.html

24. Links PS, Gould B, Ratnayake R. Assessing suicidal youth with antisocial, borderline, or narcissistic personality disorder. Can J Psychiatry (2003) 48(5):301-10

25. Roth KB, Borges G, Medina-Mora ME, Orozco R, Ouéda C, Wilcox HC. Depressed mood and antisocial behavior problems as correlates for suicide-related behaviors in Mexico. J Psychiatr Res (2011) 45(5):596-602. doi:10.1016/j.jpsychires.2010.10.009

26. Douglas KS, Lilienfeld SO, Skeem JL, Poythress NG, Edens JF, Patrick CJ. Relation of antisocial and psychopathic traits to suicide-related behavior among offenders. Law Hum Behav (2008) 32(6):511-25. doi:10.1007/s10979007-9122-8

27. Garvey MJ, Spoden F. Suicide attempts in antisocial personality disorder. Compr Psychiatry (1980) 21(2):146-9. doi:10.1016/0010-440X(80)90092-9

28. Pompili M, Ruberto A, Girardi P, Tatarelli R. Suicidality in DSM IV cluster B personality disorders. An overview. Ann Ist Super Sanita (2004) 40(4):475-83.

29. Ervin JD, Swilaski M. Low-Cost Innovations: Community Outreach through Children's Programs. The Police Chief. (2004). Available from: http:// www.policechiefmagazine.org/magazine/index.cfm?fuseaction=display_ arch\&article_id=404\&issue_id=92004

30. Criminal Justice Policy Research Institute. Decreasing Crime By Increasing Involvement: A Law Enforcement Guidebook For Building Relations In MultiEthnic Communities. Portland, OR: Criminal Justice Policy Research Institute (2011). 75 p.

31. Seattle Police Department. Community Outreach (2016). Available from: http://www.seattle.gov/Police/community/default.htm

32. Hoffman K, Bania M. Learning from Community-Based Crime Prevention Initiatives: The Experience of Three Ottawa Communities. Ottawa: Crime Prevention Ottawa (2012). 41 p.

Conflict of Interest Statement: The author declares that the research was conducted in the absence of any commercial or financial relationships that could be construed as a potential conflict of interest.

Copyright (C) 2016 Sher. This is an open-access article distributed under the terms of the Creative Commons Attribution License (CC BY). The use, distribution or reproduction in other forums is permitted, provided the original author(s) or licensor are credited and that the original publication in this journal is cited, in accordance with accepted academic practice. No use, distribution or reproduction is permitted which does not comply with these terms. 